\title{
Evaluation of Combination Chemotherapy Effect of Platinum, Vincristin, Bleomycin, and Mitomycin C on Cervical Cancer Based upon Apoptosis Description
}

\section{Penilaian Efek Kemoterapi Kombinasi Platinum, Vincristin, Bleomisin dan Mitomisin C pada Karsinoma Serviks Berdasarkan Gambaran Apoptosis}

\author{
Agus Hasan, Syahrul Rauf, Umar Malinta \\ Department of Obstetrics and Gynecology \\ Faculty of Medicine University of Hasanuddin/ \\ Dr. Wahidin Sudirohusodo Hospital \\ Makassar
}

\begin{abstract}
Objective: To observe the success of platinum, vincristin, bleomycin and mitomycin C (PVB-MMc) combination chemotherapy on cervical carcinoma by evaluating apoptosis feature.

Methods: This study was performed at Dr. Wahidin Sudirohusodo Hospital and several other hospitals. The method of this study was prospective longitudinal. Cervical biopsy was performed on 15 cervical carcinoma patients before and after PVB-MMc chemotherapy. Six patients were at early stage and 9 patients were at advanced stage. Biopsy result were sent to pathologic anatomic laboratory to be made into paraffin block and further examined for apoptosis with Tunel method. Data were analyzed by using Wilcoxon Signed Rank test.

Results: Study results indicating no significant difference for apoptosis index before and after PVB-MMc chemotherapy for early stage $(\mathrm{p}=0.463)$, advance stage $(\mathrm{p}=0.594)$, but quantitatively there were increasing apoptosis index before and after chemotherapy.

Conclusion: Chemotherapy combination PVB-MMc for cervix carcinoma can increase apoptosis index and give a good response in term of reducing the tumor size although statistically not significant.

[Indones J Obstet Gynecol 2012; 36-4: 200-5]

Keywords: apoptosis, cervical carcinoma, PVB-MMc combination chemotherapy.
\end{abstract}

\section{Abstrak}

Tujuan: Penelitian ini bertujuan mengetahui keberhasilan kemoterapi kombinasi platosin, vincristin, bleomisin dan mitomisin C (PVB$M M c)$ pada karsinoma serviks dengan menilai gambaran apoptosis.

Metode: Penelitian ini dilakukan di BLU RS Dr. Wahidin Sudirohusodo dan jejaring. Metode penelitian yang digunakan adalah longitudinal prospektif. Dilakukan biopsi serviks terhadap 15 pasien karsinoma serviks sebelum dan sesudah kemoterapi PVB-MMc. Enam pasien stadium dini dan sembilan stadium lanjut. Hasil biopsi dikirim ke laboratorium Patologi Anatomi untuk dibuat blok parafin dan selanjutnya apoptosis diperiksa dengan metode Tunel. Data dianalisis dengan menggunakan uji Wilcoxon Signed Rank test.

Hasil: Hasil penelitian ini menunjukkan tidak ada perbedaan bermakna indeks apoptosis sebelum dan sesudah kemoterapi PVB-MMc pada stadium dini ( $p=0,463)$, stadium lanjut $(p=0,594)$, tetapi secara kuantitatif ada peningkatan indeks apoptosis sebelum dan sesudah kemoterapi.

Kesimpulan: Pemberian kemoterapi kombinasi PVB-MMc pada karsinoma serviks dapat meningkatkan indeks apoptosis dan member respons klinik yang baik terhadap perubahan ukuran tumor walaupun secara statistik tidak bermakna.

[Maj Obstet Ginekol Indones 2012; 36-4: 200-5]

Kata kunci: apoptosis, kanker serviks, kemoterapi kombinasi PVB-MMc.

Correspondence: Agus Hasan. Jln. BTN Puri Istambul Blok B/49 Hertasning Baru, Makassar. Telephone/mobile: 081355148254 email: agushasan93@yahoo.com

\section{INTRODUCTION}

Cancer or malignancy is a disease which marked with an abnormal growth and spread of tissue. Cervical carcinoma is still the second most common malignancy causing death in the world. Geographically, it is still more commonly found in developing country. More than $80 \%$ of the cases were found in low-income countries in Africa, Melanesia, Latin America, Middle Asia and South East Asia. ${ }^{1}$

In the United Stated, cervical cancer is the third most common gynecological malignancy, responsi- ble for $20 \%$ of all malignancy. In 1994, there were approximately 15,000 newly diagnosed patients and 4,600 deaths. ${ }^{2}$

The incidence of cervical cancer in Indonesia ranged at 100-190 out of 100,000 people per year. But until now, the survival rate has only reached $52 \%$. To improve the outcome of treatment, new studies focused on finding new management strategy are needed. One of the best strategy for cancer management is to induce apoptosis. ${ }^{2}$ 
Recently, studies in the field of cancer is focused on identifying apoptosis involved in tumor development and observing the outcome of therapy. Apoptosis or cell-death program is a program controlling physiologic growth of cell and balancing tissue development.

Common strategy performed in clinical oncology to eliminate tumor cells are chemotherapy, radiation and immunotherapy. These strategies are associated with activating transduction for apoptosis signal. Cells failing to undergo apoptosis shows that cells are resistent to treatment. ${ }^{3,4}$

Cancer cell's ability to respond to chemotherapy is a part of its apoptosis capacity. The regulation of apoptosis could influence the resistency towards chemotherapy, thus influence the outcome of treatment. Effectivity of several chemotherapy drugs are very depended on the ability of cancer cell to undergo chemotherapy-induced apoptosis. ${ }^{2}$

Unlike radiation and surgery, chemotherapy is a treatment of cancer using drugs or hormone. Chemotherapy could be used in both localized or metastized lesion. In the beginning, chemotherapy is only a palliative treatment, but recently it was found that several type of cancers could be treated with chemotherapy.

The use of combination chemotherapy has shown significant succeed, especially in the combination of drugs with different mechanism of action. The advance of treatment in several type of cancer is achieved by using several types of drugs sequentially. ${ }^{5}$

Chemotherapy could be curative or palliative, and could act both regionally or systemic. The duration of chemotherapy regiment is different, depending on whether it is meant for palliative or curative purpose. For palliative regiment, evaluation is performed on the second cycle. Meanwhile, neoadjuvant chemotherapy is given in 12-18 weeks, with recovery period of 4-6 weeks. ${ }^{6}$

The treatment of advanced stage cervical cancer in Makassar is mainly by neoadjuvant chemotherapy, due to inadequate radiotherapy facilities. The regiment currently being used is the combination of 3 drugs, namely cisplatin, vincristin, and bleomicin (PVB) or 4 drugs, with an additon of mitomycin C.

Vogl et al reports a response rate of $77 \%$ on the use of neoadjuvant chemotherapy (PVB-MMc). The effectivity of the regiment has also been proven by
Gynecological Cancer Group (GCG) from EORTC in squamos cell cervical carcinoma with the following dose: bleomycin $30 \mathrm{UI}$, vincristine $0.5 \mathrm{mg} / \mathrm{m}^{2}$, mitomycin-C $10 \mathrm{mg} / \mathrm{m}^{2}$ and cisplatin (platosin) 50 $\mathrm{mg} / \mathrm{m}^{2}$. PVB-MMc dose currently used in Makassar is bleomycin $30 \mathrm{UI}$, vincristine $0.5 \mathrm{mg} / \mathrm{m}^{2}$, mitomycin-C $20 \mathrm{mg} / \mathrm{m} 2$ and cisplatin $50 \mathrm{mg} / \mathrm{m}^{2}$. The cummulative dose of mitomycin-C can't be more than $50 \mathrm{mg} / \mathrm{m}^{2}$ in combination chemotherapy. ${ }^{7}$

Sharviyanti et al performed study in 71 advanced stage cervical cancer patients. There were 29 cases (40.85\%) became operable after 2 series of chemotherapy, but 42 cases (59.15\%) remained inoperable. From 29 cases became operable, 22 cases $(75.9 \%)$ gave complete response with histopathology examination showed no malignant cell in cervix, uterus, adnexa and lymph node. And 7 cases (24.1\%) still shows partial response and malignant cells were still found. From 42 cases remained inoperable, $2(4.77 \%)$ were non responsive and 40 other cases (95.23\%) gave partial response because the tumor used to be very exophitic and bulky (diameter $>4 \mathrm{~cm}$ ) had reduced in size but there were still process in the parametrium. There was no severe toxic response from this research. ${ }^{8}$

Based on this research, we saw the need for further studies for PVB-MMc regiments, mainly to see the effect it has on the apoptosis of cancer cells.

\section{METHOD}

This study was performed in the Institutional Hospital Department of Obstetrics and Gynecology, Faculty of Medicine, University of Hasanuddin, Makassar. Dr. Wahidin Sudirohusodo Hospital and the satellite hospitals, from March 2011 until February 2012. The method of this study was prospective longitudinal, aimed to observe the relationship between combination chemotherapy regiment of Platinum, Vincristin, Bleomycin and Mitomycin C with apoptosis index in the cervical cancer patients.

The subject of this study was patients diagnosed as having cervical cancer in Dr. Wahidin Sudirohusodo Hospital or other satellite hospitals, and planned to receive combination chemotherapy regiment of Platinum, Vincristin, Bleomycin and Mitomycin C. Subject must agree to join the study and fulfilled the inclusion criteria. Data was acquired by performing anamnesis, physical and laboratory examination, and histopathology examination, and immunohistochemical examination to detect apop- 
tosis cells with TUNEL (T-UTP Nick End Labeling) method using In Situ Cell Death Detection kit Apop$\mathrm{Tag}^{\circledR}$ in paraffin block tissue preparation.

Data will be categorized and analyzed using SPSS for window version 17 . The analysis was performed using Wilcoxon Signed Ranks Test and the result would be considered significant if $\mathrm{p} \leq 0.05$.

\section{RESULT}

His study was performed on 15 patients who undergone two times cervical biopsy, once before and once after the chemotherapy. The tissue will be fixated in $10 \%$ formalin and then sent to Pathology anatomy laboratorium to be processed into paraffin block preparation and examined to detect apoptosis with TUNEL method.

\section{Subject Characteristic}

The characteristic of the subjects was summarized in Table 1.

Table 1. Subject Characteristics

\begin{tabular}{lcc}
\hline \hline \multicolumn{1}{c}{ Variable } & Frequency & $\begin{array}{c}\text { Percentage } \\
\text { (\%) }\end{array}$ \\
\hline Age group & & \\
$\quad$ 45 years old & 5 & 33.33 \\
$>$ 45 years old & 10 & 66.67 \\
Parity & & \\
$\quad$ Primipara & 0 & 0 \\
$\quad$ Multipara & 15 & 100 \\
Educational background & & \\
$\quad$ Elementary school & 4 & 26.67 \\
$\quad$ Junior high school & 4 & 26.67 \\
$\quad$ Senior high school & 7 & 46.66 \\
History of contraception & & \\
$\quad$ None & 5 & 33.33 \\
DMPA & 7 & 46.67 \\
IUD & 3 & 20.00 \\
Stage & & \\
Early & & \\
Advance & 6 & 40.00 \\
Histopathology & 9 & 60.00 \\
Squamous cell & & \\
Adenosquamous & 10 & 66.67 \\
Adenocarcinoma & 3 & 20.00 \\
\hline \hline
\end{tabular}

In Table 1, we could see that most patients were in over 45 years old group $(66,67 \%)$, with the youngest patient being 30 years old and the oldest being 65 years old. According to parity, all pa- tients were multiparous, with 2-8 children. Most patients graduated senior high school (46.66\%). The most common contraception used by subject was DMPAs (46.67\%).

Most cases were in advanced stage (60\%) and the most common histopathologic type was squamous cell carcinoma (66.67\%).

The effect of chemotherapy in apoptosis index and tumor size in early stage cancer.

Table 2. The difference in apoptosis index and tumor size before and after chemotherapy in early stage cancer

\begin{tabular}{ccc}
\hline \hline Variable & $\mathbf{n}$ & $\mathbf{p}^{*}$ \\
\hline Apoptosis index & & \\
Increasing & 4 & 0.463 \\
Decreasing & 2 & \\
No change & 0 & \\
Tumor size & & 0.026 \\
Increasing & 0 & \\
Decreasing & 6 & \\
No change & 0 & \\
\hline \hline
\end{tabular}

*Wilcoxon Signed Rank test

In 6 cases of early cervical carcinoma (Table 2) the apoptosis index showed no significant change before and after chemotherapy, with $\mathrm{p}=0.463$ $(\mathrm{p}<0.05)$. But there were 4 cases with increasing apoptosis index and 2 cases with decreasing apoptosis index, meaning that chemotherapy still showed effects in apoptosis index quantitatively.

But in all cases, the tumor size reduced significantly with $\mathrm{p}=0.026(\mathrm{p}<0.05)$, showing significant effects both clinically and statistically of PVB-MMc in tumor size.

\section{The effect of chemotherapy in apoptosis index and tumor size in advanced stage cancer}

Table 3. The difference in apoptosis index and tumor size before and after chemotherapy in advanced stage cancer

\begin{tabular}{ccc}
\hline \hline Variable & $\mathbf{n}$ & $\mathbf{p}^{*}$ \\
\hline Apoptosis index & & \\
Increasing & 6 & 0.594 \\
Decreasing & 3 & \\
No change & 0 & \\
Tumor size & & 0.498 \\
Increasing & 2 & \\
Decreasing & 3 & \\
No change & 4 & \\
\hline \hline
\end{tabular}

\footnotetext{
* Wilcoxon Signed Rank test
} 
In the patients with advanced stage cancer, out of 9 cases, there were 6 patients showing increasing apoptosis index while 3 patients showed decreasing apoptosis index. Statistical analysis gave $\mathrm{p}=0.594(\mathrm{p}>0.05)$, meaning that chemotherapy in advanced stage cancer did not show significant result. But when we looked at the result clinically, 6 cases did show increasing apoptosis index, and it was a significant number of patients. Thus PVB$M M c$ regiment could still be a choice in the treatment of cervical carcinoma.

Based on the tumor size (Table 3), three cases $(33.33 \%)$ decreased in size, two cases increased $(22.22 \%)$, while the rest four cases $(44.44 \%)$ stayed in size. Statistical analysis gave $p$ value of $p=0.498$ ( $p>0.05)$, meaning that it is statistically insignificant, but clinically there were seven cases (77.7\%) which responded well to chemothrapy, thus chemotherapy is still recommended because it could maintain or even reduce the size of the tumor.

The most commonly found histopathology type in this study was squamous cell carcinoma (66.67\%). Almost $70 \%$ of all squamous cell carcinoma cases had an increaseing apoptosis index. This is similiar with the other histopathology types. It showed that chemotherapy could increase apoptosis index, regardless of the histopathological type.

\section{DISCUSSION}

This study was conducted by taking a biopsy sample of 15 cervical carcinoma lesion in patients before and after chemotherapy combination PVBMMc fit the inclusion criteria. The first biopsy was performed before the administration of chemotherapy and the second biopsy performed after the patients undergoing 2 series chemotherapy.

Table 1 shows the characteristics of the data such as age, parity, education, history of contraceptive use, stage and type of carcinoma cells. Most subjects were over 45 years (66.67\%). Turah et al had the same high percentage of subjects in that age group $(56.7 \%))^{9}$ Different results were obtained by Sulina, where approximately $43 \%$ tof the subjects were less than 45 years old. ${ }^{10}$ In the United States, the average age of women with cervical carcinoma was 52.2 years. Age variation may be different due to several factors such as not optimal screening, socio-economic status, educational background and the level of knowledge in the community about the disease.

All subjects had more than 2 children. One of the risk factors for cervical carcinoma is multiparity. Sulina et al got the same result, ie $100 \%$ of the patients was multiparous. ${ }^{10}$ Trauma in labor may be a predisposing factor for the development of precancerous lesions that can subsequently become carcinoma.

Education level of secondary education were found in $73.3 \%$ of the subjects. The different results were obtained by Turah that most subjects had only the primary education $(56.7 \%) .{ }^{9}$

Approximately $66.7 \%$ of the subjects had a history of contraception. Some epidemiological data showed that hormonal was one of the risk factors. But keep in mind that the incidence of carcinoma of the cervix is a complex interaction of several cofactor. ${ }^{11}$

Most subjects (60\%.) in this studies were at the advanced stage of the disease. Both Turah and Sulina found that $50 \%$ of the subjects were in advanced stage. Early signs of cervical carcinoma is not specific, such as the presence of vaginal secretion, sometimes alongside a spot bleeding. Generally very minimal signs are often ignored by the patient so that they come up with an advanced stage. ${ }^{9,10}$

According to the histopathological type, squamous cell carcinoma is the most common type (66.7\%) in this study. Hung obtained the results in 30,989 patients that two-thirds of the patients had squamous cell carcinoma.

Apoptosis is a programmed cell death occuring during normal development and the aging process as a homeostatic mechanism to maintain cell populations in the tissue. ${ }^{12}$

Mechanism for apoptotic cell death could occur via several pathways: 1 ) through p53. When cells undergo DNA damage, it activates the p53 gene which will stop the signal through the p21 CDK phosphorylation that in turn will stop the cell cycle. If DNA is not successfully repaired the p53 gene will promote apoptosis, 2) direct stimulation of apoptosis pathway mechanism to caspasen through TNF receptors, 3) apoptosis may be induced by $\mathrm{T}$ lymphocytes (cytotoxic) and natural killer cells, 4) proapoptotic and antiapoptotic proteins that can stimulate or inhibit the induction of apoptosis, such as the $\mathrm{BCl} 2$ family gene. ${ }^{7}$ 
DNA damage in cells can induce apoptosis through p53 pathway. DNA damage can be triggered by various kinds of stimuli such as radiation and drugs used in therapy kanker. ${ }^{12}$ Wild-type p53 is able to suppress cell transformation induced by oncogenes and may inhibit potential tumoregenic whereas p53 present in cells transformed a mutant form $\mathrm{p} 53 .{ }^{13}$

Under normal circumstances p53 tetramer consisting of 4 identical copies, assembled into the form of activated p53 molecule. The consequence of a defect in one of the 4 subunit is it weakens the function of proteins. And if the cell has 1 wild-type allele and the other allele is defective, then the majority of p53 function will be compromised. ${ }^{13}$

Table 2 and 3 presented the effect of chemotherapy on apoptotic index in early and advanced stage, and it was not statistically significant but there was an increase in apoptotic index after administration of chemotherapy. The increasing apoptotic index happened in 4 early stage cases $(66.7 \%)$ and 6 advanced stage cases $(66.7 \%)$. DNA damage in cells caused by chemotherapy can induce apoptosis through p53 (wild type), depending on the apoptotic ability of wild-type p53. In the 1990's, it was known that p53 regulates the cell cycle checkpoint which is responsible for DNA damage.

In the presence of DNA damage, p53 cells hold for the next phase and allow time for the DNA to make repairs, or if the damage is severe enough, the p53 will initiate programmed cell death (apoptosis). A lost of several molecular checkpoints can be found in the development of some tumors, this is due to cell cycle progression to function properly. Accumulation of genetic changes also play a role in the onset chemoresistant, which resulted in the loss of ability to respond to DNA damage. ${ }^{7}$

In general, p53 mutations in one allele followed by deletion of the other allele will caused both alleles to become inactive or not working. $17 \mathrm{p}$ deletion allele occurred at least in $60 \%$ of colon, breast, lung, ovarian, cervical cancer and at least $30 \%$ of brain cancer. Most of the cancers that had $17 \mathrm{p}$ deletion allele contain mutant $\mathrm{p} 53$. This means that p53 mutations occur during the process of tumorigenesis and that cancer grows through dominantly negative effect. ${ }^{14}$ Loss of the lost of p53 function is frequently observed in cancer, thus could be used as the basic of administering substance whose function is similar to the p53 gene. In the future, it is likely that a more directed ther- apy will be developed to replace the defective gene through suicide gene therapy. ${ }^{12}$

In addition to p53 mutant as the cause of decreasing apoptotic index after chemotherapy, the dose of medication could also have some effect. At low doses, different types of stimuli such as high temperature, radiation, hypoxia and anticancer cytostatic can induce apoptosis, but in high doses, the same stimulus may result in necrosis of the cell. ${ }^{12}$

Table 3 shows that the size change of the tumor in response to chemotherapy in early-stage cervical carcinoma happened in $100 \%$ cases, and was statistically significant. But in advanced cervical carcinoma, we found that 3 cases (33.33\%) experienced tumor shrinkage, 2 cases (22.22\%) grew, and 4 cases (44.44\%) were fixed in size, and it was not statistically significant. Kim (1988) conducted a study on 35 patients of cervical carcinoma stage Ib-IIa with PVBM regimen and 89\% cases reported to have a complete response. Sharvianty (2006) reported 71 patients of advanced cervical carcinoma treated with PVB-MMc. There were 22 cases that showed a complete response (histopathological examination showed that there were no malignant cells either in the cervix, uterus, adnexa and lymph nodes), 40 cases assessed as partial response as the original tumor is very exophytic and bulky (diameter $>4 \mathrm{~cm}$ ) and had become very small, but there is still a process in the parametrium.

Administration of chemotherapy can cause tumor regression so that it can be used as one measure to objectively assess the effectiveness of treatment. Criteria for clinical effectiveness of treatment include: complete response if the tumor mass has disappeared on examination 4 weeks after 2 series of chemotherapy. Partial response is a reduction in the diameter of the largest tumor size and perpendicular by $50 \%$ or more without any growth of new lesions for 4 weeks. Tumors are stable if there is no increase in tumor size or tumor shrink to the size of a very minimal, and progressive lesions that showed an increasing size of over $50 \%$ or the tumor was found elsewhere. ${ }^{5}$

The increasing size of the tumor after chemotherapy can be caused by drug resistant (multidrug resistance), which increased the presence of 170$\mathrm{kDa}$ transmembrane glycoprotein (P170 or glycoprotein) which is the product of the MDR1 gene. This glycoprotein plays a role in the mechanism of drug efflux pumps. Increased expression of P170 glycoprotein causes an increase in the incidence of 
chemotherapy resistance. Due to the occurrence of multiple mechanisms of resistance through the mechanisms of DNA repair, drug accumulation due to decreased influx mechanism, the process of inactivation by glutathione, methalothion or inactivation due to protein binding. It can be concluded that the mechanism of chemotherapy resistance through molecular cell review focused on two genes that play a major role, namely wild-type p53 and Bcl2. P53 mutations will increase the resistance of cells. Increased Bcl2 which acts as an inhibitor of apoptosis is also one of the mechanisms of resistance to chemotherapy. ${ }^{7}$

A lot of literature written about $85-90 \%$ of cervical carcinoma cell carcinoma squamousa manifold, the rest is kind of different histology. Type of cervical histopathology does not affect the apoptotic index.

Apoptosis is strongly influenced by the p53 pathway. Research conducted in the laboratory showed that HPV has a protein coat that produces some oncoprotein. Oncoprotein E6 is an oncoprotein that affect p53 and can make it less or even inactive. If the E6 oncoprotein is binding, it will cause a mutagenesis effect on cell growth so that the cell growth can not be controlled. ${ }^{11}$

\section{CONCLUSION}

PVB-MMc combination chemotherapy in cervical carcinoma may increase the apoptotic index and give a good clinical response to changes in tumor size, although not statistically significant. Further studies need to be done on mutant p53 as an important factor of the increasing apoptosis index.

\section{REFERENCES}

1. Martin ACL, Carballo N, Garcia J, Lapuente F, Rojo A, Chiva L. The Current Role of Neoadjuvant Chemotherapy in the Management of Cervical Carcinoma. Gynecol Oncol. 2008; 110-536.

2. Hempling RE. Cervical Cancer in Handbook of Gynecologic Oncology, New York, Library of Congress Cataloging .1996.

3. Fulda S, Debatin, K. Extrinsic versus intrinsic apoptosis pathways in anticancer chemotherapy. Oncogene 2008.

4. Stacey R, Zong W. Chemotherapeutic Approaches for Targeting Cell Death Pathways. The Oncologist 2006.

5. Saleh AZ. Kemoterapi. Buku Acuan Nasional Onkologi Ginekologi. Edisi Pertama ed. Jakarta, Yayasan Bina Pustaka Sarwono Prawirohardjo 2006.

6. Garimella VW, Watson BM. Assesment of Apoptotic Markers as Predictors of Response to Neoadjuvant FEC Chemotherapy in Locally Advanced Breast Cancer. Research Article 2007.

7. Andrijono. Kanker Serviks Uteri dalam Sinopsis Kanker Ginekologi, Jakarta, Pustaka Spirit 2009.

8. Arifudin S. Peran Kemoterapi Neoadjuvant pada kanker serviks stadium lanjut. Dibawakan dalam Kongres Nasional Perhimpunan Onkologi Indonesia 8 September 2006.

9. Turah. Peranan Kadar Petanda Tumor Antigen Karsinoma Sel Squamous dan Antigen Embrionik Karsinoma dalam Menilai Respon Klinik pada Kanker Serviks Stadium Lanjut yang Diberikan Kemoterapi BOMP, tesis tidak diterbitkan, Makassar: Program Pasca Sarjana FK UNHAS 2009.

10. Sulina. Hubungan Indeks Apoptosis dengan Tipe Histologi, Diferensiasi Sel dan Stadium Klinis Penderita Kanker Serviks, Tesis tidak diterbitkan. Makassar, Program Pasca Sarjana FK UNHAS 2010.

11. Putra AD. Lesi Prakanker Serviks. Buku Acuan Nasional Onkologi Ginekologi. Edisi Pertama ed. Jakarta, Yayasan Bina Pustaka Sarwono Prawirohardjo. 2006.

12. Kresno S. Apoptosis. Ilmu Dasar Onkologi edisi kedua. Jakarta. Badan Penerbit FK-UI 2010.

13. Levine AJ. Tumor suppressor gene in The Moleculer Basis of Cancer, Philadelphia, WB Saunders 1955.

14. Cooper GM. Role of Oncogenes and Tumor suppressor genes in the pathogenesis of human cancers. In: Cooper GM: Oncogenes (2nd ed), Boston. 1955. 